\title{
Rapid changes in snow cover at low elevations in the Sierra Nevada, California, U.S.A.
}

\author{
RichaRd KatTELmanN \\ Sierra Nevada Aquatic Research Laboratory, Star Route 1, Box 198, Mammoth Lakes, CA 93546, U.S.A.
}

\begin{abstract}
Snow cover in the intermittent snow zone of the Sierra Nevada can occupy more than $10000 \mathrm{~km}^{2}$ of the mountain range, but it has received relatively little attention in river forecasting. Snow is deposited at lower elevations only during the cold storms of winter, and remains there only for a few days or weeks. When cold storms have created a thin snow cover at low elevations, a subsequent warm storm can melt this snow in just a few hours and increase the runoff response dramatically. Operational hydrological models and river-forecasting procedures have tended to overlook contributions from the intermittent-snow zone, focusing instead on rainfall-runoff or melt from the snowpack zone at higher elevations. Data-collection efforts are minimal in this zone, too. Ideally, spatially distributed models of snowmelt and runoff generation are needed to account for the typically large differences in snow cover on different aspects in the intermittent snow zone. Although aircraft and satellite imagery would be most desirable to monitor the distribution of snow cover in the intermittent-snow zone, even a few climate stations that report precipitation type and snow presence would be a major improvement over the present situation in the Sierra Nevada.
\end{abstract}

\section{INTRODUCTION}

Before the onset of sustained snowmelt runoff in spring from the snowpack zone at higher elevations, most of the winterseason streamflow in the Sierra Nevada is produced in the intermittent-snow zone (Anderson, 1958). Both rainfall and snowmelt contribute to this mid-winter runoff. The intermittent- (or transient-) snow zone may be defined casually as areas where snow is present for one week to three months in most years. The intermittent-snow zone is a dynamic region that may have substantially different conditions within and between winters. Snow cover may accumulate and ablate completely several times during a winter in these areas. Slopes at low elevations with southern exposure are especially prone to rapid disappearance of snow cover following storms. When snow lingers at low elevations after a cold storm, it may melt during subsequent warm storms, and augment the runoff dramatically. Because there is rarely sufficient energy available to melt much snow in the higher-elevation snow pack zone during all but the warmest winter storms, the presence of snow cover at low elevations, where temperatures may be up to $+15^{\circ} \mathrm{C}$, is the critical factor in the augmentation of rainfall-runoff. In some storms, the availability of snow at low elevations can determine the magnitude of flood peaks. The purpose of this paper is to illustrate the potential importance of transient snow cover at low elevations in the Sierra Nevada and underline that the lack of monitoring of snow below the seasonal-snowpack zone can have repercussions for local hydrological forecasting.

\section{GENERAL GEOGRAPHY}

The Sierra Nevada extends roughly northwest-southeast for more than $600 \mathrm{~km}$ along the eastern side of California, and averages about $100 \mathrm{~km}$ in width. The area's Mediterranean climate results in a strongly seasonal precipitation pattern, with about half of the average annual precipitation occurring in winter and another third in late autumn. Average annual precipitation ranges from about 700-1200 mm. The most intense warm storms of long duration tend to occur during mid-winter when snow is likely to cover part of the larger river basins. These warm storms can bring rain to the highest parts of the range and release enough energy to the snowpack to produce substantial augmentation of the rainfall-runoff. Streamflow generated below $\sim 1000-1500 \mathrm{~m}$ is usually directly associated with storms, while streamflow above $2500 \mathrm{~m}$ is almost entirely a product of spring snowmelt. Between these approximate elevations, streamflow is generated both by runoff from warmer storms, and by snowmelt from April to July.

The intermittent-snow zone of the Sierra Nevada covers more than a third of most river basins on the west slope of the mountain range. Most of this terrain consists of steep slopes and the narrow canyons of tributaries to the main rivers. Most of the rivers flow from east to west, leading to strong contrasts in the moisture and energy characteristics between the north and the south sides of the canyons. In most years, the intermittent-snow zone includes elevations $\sim 700$ $1200 \mathrm{~m}$ in the northern Sierra Nevada and $1200-1800 \mathrm{~m}$ in the southern part of the range. These general-elevation ranges also vary with aspect, and snow cover is usually discontinuous within the zones. The upper portion of the intermittent-snow zone extends into the mixed-conifer forest, which is the principal vegetation type in most river basins of the western slope of the Sierra Nevada. The oak woodland and chaparral vegetation types also develop temporary snow cover during the coldest storms. The dense vegetation 
of these different types can intercept several mm of snow water equivalent (SWE). Interception storage in the diverse plant canopies found in the intermittent-snow zone can range from 0.3 to $9 \mathrm{~mm}$ (U.S. Army Corps of Engineers, 1956). Much of the water detained in the canopy falls to the ground as clumps of wet snow or meltwater during or soon after a snowstorm (e.g. Miller, 1962). Once on the soil or litter layer, the snow is subject to melting from conductive heat transfer from the ground because of the prevailing warm temperatures at these lower elevations between storms.

\section{RAIN-ON-SNOW FLOODS}

Major rivers of the west slope of the Sierra Nevada tend to have their highest flows when warm winter storms interact with extensive snow cover. Although storm rainfall is the overwhelming source of runoff, the contribution of snowmelt can add to flooding and associated damage (e.g. Harr, 1981). The greatest historic floods of the principal rivers of the mountain range have occurred under rain-on-snow conditions (Kattelmann and others, 1991). Cities and farms in California's Central Valley have been inundated numerous times in the past 150 years when rainfall was augmented by snowmelt. Considerable damage is often caused to roads and bridges within the forest zone, and extensive damage to the rural road system was observed following warm storms in 1982, 1983, 1986, and 1995. Channel erosion and mass movement are other common results from rain-onsnow events in this area (e.g. Bergman, 1987).

The first well-documented rain-on-snow flood in California occurred 9-12 January 1862. This flood was generated by an intense storm that followed more antecedent precipitation than usually falls in a year. Historical accounts described the importance of snowpack contributions to this flood: $20 \mathrm{~cm}$ of snow was reported in the northern Sacramento Valley and $30 \mathrm{~cm}$ covered areas below the foothills (Sacramento Union Jan. 7, 1862). This extensive snow cover in the Sierra Nevada foothills must have contributed vast amounts of water to the flood. Snowmelt was also mentioned in descriptions of the two major Californian floods of the early 20th century (Taylor, 1913). Before the March 1907 flood, snow was observed to have covered the entire Sacramento Valley.

Better documentation of streamflow and weather conditions has been available since the 1930s. Weather and snowpack records indicate that snowmelt contributed to each of the major floods of this century in most of the rivers of the western slope (Kattelmann and others, 1991). A series of warm storms in mid-February 1986 produced substantial runoff in rivers of the northern Sierra Nevada that severely stressed the flood-control operations of several dams. The peak flow in 1986 was less than those in the floods of 1950 , 1955, 1963 and 1964, but the total volume was much greater in 1986 because of the storm's long duration. Fluctuating freezing levels during the week of storms alternately deposited and then melted snow.

During the historic period (1850 to present), warm storms have been rare during spring in the Sierra Nevada. The one large flood of this type occurred in April 1982, and ranks in the top 10 floods in the annual flood scries in many headwater streams. Another rare warm storm in spring, which brought rain above $3500 \mathrm{~m}$, occurred in May 1996. There are only a few other moderate rain-on-snow events superimposed on spring snowmelt floods in the streamflow record. The intermittent-snow zone is quite unlikely to contain snow during the spring.

\section{ROLE OF SNOW COVER IN FLOOD GENERATION}

The potential for flood production from warm storms is related to their large contributing area, duration and intensity of rainfall, opportunity for snowmelt contributions, and the timing of release of water from the snowpack in some cases. The main factor is the increase in contributing area with rainfall-runoff production from the higher-elevation portions of river basins that receive snow during most winter storms. During the warmest storms, the effective area of some drainage basins may become several times larger than during more typical storms that deposit snow over most of the area. The sheer quantity of rainfall in larger storms is obviously the main source of runoff.

When snow is present during warm storms, the opportunity to augment rainfall-runoff with snowmelt is also present. Snow melts by convective heat exchange and condensation when temperatures are high and winds are strong. The potential for significant snowmelt contributions is greatest when snow occurs at very low elevations, where sufficient energy is available to melt substantial amounts of snow (Harr, 1981). In the Sierra Nevada, snow falls at elevations below $300 \mathrm{~m}$ a few times per decade and occurs below $1000 \mathrm{~m} \sim 2$ times in most years. Although snow at these low elevations rarely persists for more than a few days after it is deposited, it is temporarily available for melt and runoff. Snowmelt at low elevations, where air temperatures are warmer than $10^{\circ} \mathrm{C}$ or even $15^{\circ} \mathrm{C}$, can exceed $50 \mathrm{~mm}$ in 24 hours under severe convection/condensation conditions during warm, windy storms. A detailed analysis of three rain-on-snow events $(1963,1964,1982)$ in the American River basin indicated that snowmelt added more than $50 \mathrm{~mm}$ of water at lower elevations and could have been greater if more snow was present (Hall and Hannaford, 1983). With increasing elevation, less snow melts because less energy is available. In most years, relatively little snowmelt occurs at clevations above $2000 \mathrm{~m}$ during rain-on-snow events in the Sierra Nevada (Bergman, 1983).

The Blue Canyon weather station in the northern American River basin (at $1600 \mathrm{~m}$ ) has the most complete snow records of any site in the intermittent-snowpack zone of the Sierra Nevada, and is suggestive of the availability of snow at lower elevations and the potential for the augmentation of runoff. At this site, seasonal peak water equivalence varied from 9 to $70 \mathrm{~cm}$ between 1960 and 1980, inclusive (Kattelmann and McGurk, 1989). Maximum SWE was less than $25 \mathrm{~cm}$ in 8 years and more than $50 \mathrm{~cm}$ in 5 of the 21 years examined. Complete disappearance of snow cover at this site was often a limiting factor in the generation of runoff during warm storms. Records of outflow from snowmelt lysimeters at this site indicated that water release from the shallow snow pack exceeded $50 \mathrm{~mm} \mathrm{~d}^{-1}$ during 15 rain-onsnow events between 1985 and 1988 (Kattelmann and McGurk, 1989).

Significant amounts of snow were present at low elevations at the onset of the warm storm that led to record flooding in parts of the Pacific Northwest in February 1996. Melt of $>25 \mathrm{~cm}$ SWE was observed at some monitoring sites during that period. That event was a dramatic reminder of 
the potential for major additions to rainfall-runoff from snowmelt under the unusual conditions of relatively thick snow cover present throughout a basin at the beginning of a very warm storm. Such an event demonstrates that some estimates of snowmelt contributions under extreme conditions need to be revised upward. For example, a probable maximum-flood analysis for the American River basin estimated that the snowmelt contribution would be limited to $52 \mathrm{~mm}$ in 72 hours (U.S. Army Corps of Engineers, 1991).

\section{EXISTING DATA SOURGES}

The greatest uncertainties in operational flood forecasting particular to rain-on-snow events are the availability of snow for melt and the position of the rain-snow boundary. Unfortunately, there are few snow-monitoring sites in the intermittent-snow zone of the Sierra Nevada. Better knowledge regarding the amount of snow at low elevations would be helpful in estimating potential runoff augmentation during warm storms. The dynamic nature of snow cover in the intermittent-snow zone suggests that information about its condition needs to be updated frequently.

Primary information about snow cover in the Sierra Nevada is derived from an extensive network of manually measured snow courses and telemetered snow sensors. This system is administered by the California Cooperative Snow Survey program of the state's Department of Water Resources, and includes more than 300 courses and 100 sensors (Hart and Gehrke, 1990). More than 160 snow courses and more than 60 snow sensors are currently active in the major river basins on the west side of the Sierra Nevada. These measurements are mainly intended to provide the basis for seasonal volume forecasts during the April-July period of sustained snowmelt runoff. Therefore, virtually all these sites are located within the seasonal-snow pack zone. Few sites provide information about conditions in the intermittent-snow zone. Five snow courses and no snow sensors are located below $1500 \mathrm{~m}$ in the river basins of the western Sierra Nevada. About 20 snow courses and 6 snow sensors are between 1500 and $1800 \mathrm{~m}$, and might be useful for indexing conditions at lower elevations under certain conditions. Although there are about 50 stations in the study area that are part of the National Climate Center's cooperative observer network, only 10 stations record snowfall or snow on the ground.

\section{POTENTIAL DATA SOURCES AND IMPROVEMENTS IN FORECASTING}

Ideally, a rain-on-snow-forecasting scheme would estimate the SWE on a spatially-distributed basis throughout a river basin. Estimates of the amount of water stored as snow in elevation bands, gridcells, or terrain-based elements would be needed to determine the water available to contribute to runoff under different storm conditions. Although many hydrological models are available to keep track of the snowpack and calculate melt on a spatially-explicit basis (e.g. Leavesley and Stannard, 1990), there is a current lack of information about conditions in the intermittent-snow zone to initialize or update such a model for rain-on-snow forecasts. The addition of a few telemetered snow sensors to the intermittent-snow zone would be an obvious first step in obtaining more information about the snow cover in the intermittent-snow zone. Although such data are only from single points, they can be quite useful in determining whether snow is accumulating or ablating from similar environments. The Natural Resources Conservation Service, and a local agency, recently installed two SNOTEL sites at low elevations in Washington to aid in flood forecasting (Pattee and Kammereck, 1996). Another index of snowcover conditions in the intermittent-snow zone could involve snow-line reports on both north and south aspects along the few major highways and could be provided by road maintenance and highway patrol staffs.

Information about the areal extent of snow cover is also highly desirable, and has a long history of use in the Sierra Nevada for seasonal runoff forecasts. From 1952-1973, the U.S. Army Corps of Engineers obtained maps of snowcovered areas in the Sierra Nevada with an observer in a light airplane drawing the approximate snow line on an aeronautical chart. Direct visual observation of snow-covered area was regarded as superior to interpretation of aerial photographs Gerdel, 1949; U.S. Army Corps of Engineers, 1956; Parsons and Castle, 1959). The use of snowcovered area as a parameter in forecasting snowmelt runoff was thought to result in significant improvement of forecasts (Hannaford and others, 1979). Flights were generally delayed for several days following storms to allow the disappearance of the thin snow cover at low elevations. Hannaford and others (1979) suggested caution should be used when examining the transient snow line after storms, which could change rapidly and subvert interpretation of recession of the seasonal snow pack. Estimates of short-term fluctuations in snow cover of the Kings River basin were based on combined aircraft and ground observations (Court, 1963).

Data from the NOAA polar-orbiting satellite with the Advanced Very High Resolution Radiometer (AVHRR) would probably provide the most useful snow-coverage data for the intermittent-snow zone from current satellites. The relatively coarse spatial resolution of the $1 \times 1 \mathrm{~km}$ pixels of the AVHRR data is compensated by its frequent temporalrepetition cycle (Baumgartner and others, 1991; Rango, 1993). Its daily overpass during daylight provides good opportunity for cloud-free images twice each week in the Sierra Nevada during most winters. Data from the AVHRR have been used regularly in the modeling of seasonal snowmelt runoff (e.g. Martinec and Rango, 1987; Rango, 1993).

Several agencies are involved in making streamflow forecasts for the rivers of the Sierra Nevada. The California-Nevada River Forecast Center of the National Weather Service in Sacramento has primary responsibility among various agencies for flood warnings and short-term river forecasts. The Department of Water Resources of the California Resources Agency assists in these efforts, and provides much of the data-generating infrastructure on which the forecasts are based. The U.S. Corps of Engineers and Bureau of Reclamation also cooperate in making the forecasts and are responsible for releases from their reservoirs. The U.S. Geological Survey provides near real-time streamflow data. County agencies, hydroelectric operators, and water and irrigation districts are involved in making forecasts for smaller streams, monitoring and controlling their own projects, and coordinating with the other agencies. In general, the operational forecast procedures are constrained by limited data availability. Human judgment remains a critical part of most forecasts because hydrological models have yet to integrate adequately subjective 
factors and the past experience of forecasters. Hydrological models used in operational river forecasting are usually not quite state-of-the-art (i.e. research-grade tools). Nevertheless, operational models continue to be refined and modified to take advantage of new strategies and data sources (e.g. McManamon and others, 1995). For example, the concepts behind the procedures developed by Brunengo (1990) and Brunengo and others (1992) for the Pacific Northwest could be readily adapted to an operational-forecasting scheme for rain-on-snow runoff if some information were available about the snow cover. Simple indexes of snowmelt during convection/condensation conditions are effective (Beaudry and Golding, 1983; Berris and Harr, 1987), but such procedures rely on knowledge about whether snow is available to melt.

\section{CONGLUSIONS}

The intermittent-snow zone of the Sierra Nevada is a particularly dynamic region of short-term snow cover. Colder storms can cover thousands of square kilometers with thin snow, which may melt within a few hours of its deposition. When a few centimeters of SWE persist over these large areas into a subsequent warm storm, the resulting melt can increase runoff and flooding dramatically. Attempts to define average properties of snow in the intermittent-snow zone do not seem particularly useful. Perhaps the most important characteristic is the variability in snow conditions over short periods of time. Knowledge of the potential conditions and the possibilities for augmentation of runoff is the principal argument for expanding monitoring of the intermittent-snow zone. More information about the extent of snow at low elevations and its potential availability for runoff could significantly improve short-term river forecasts during warm storms.

\section{ACKNOWLEDGEMENTS}

An evaluation of the physical hydrology of the Sierra Nevada was supported by the NASA Earth Observing System program through a grant to Jeff Dozier at the University of California, Santa Barbara. Some parts of this paper were derived from studies supported by the Sierra Nevada Ecosystem Project as authorized by Congress (HR5503) through a cost-reimbursable agreement (PSW-93-001CRA) between the USDA-Forest Service, Pacific Southwest Research Station and the Regents of the University of California, Wildland Resources Center. Earlier work funded by the Pacific Gas and Electric Company is also included.

\section{REFERENCES}

Anderson, H.W. 1958. Rain snow flood sources, meteorologically defined. Bull. Am. Meteorol. Soc., 39 (3), 174-175.

Baumgartner, M. F. A. Schönenberger and U. Stalder. 1991. Snow cover variation on the AIps using NOAA-AVHRR data. International Association of Hydrological Sciences Publication 205 (Symposium at Vienna 1991 Snow, Hydrology and Forests in High Alpine Areas , 41-50.

Beaudry, P. and D. L. Golding. 1983. Snowmelt during rain on snow in coastal British Columbia. Proc. West. Snow Conf., 5lst Annual Meeting, 1921 April 1983, Vancouver, Washington, 55-66.Bergman, J. A. 1983.
Hydrologic response of central Sierra Navada snowpacks to rainfall. Proc. West. Snow Conf., 5lst Annual Meeting, 19-21 April 1983, Vancouver, Washington, 141-144.

Bergman, J. A. 1987. Rain-on-snow and soil mass failure in the Sierra Nevada of California. In DeGraff, J.V., ed. Landslide activity in the Sierra Nevada during 1982 and 1983. San Francisco, CA, USDA Forest Service. Pacific Southwest Region, 15-26. (Earth Resources Monograph 12.

Berris, S. N. and R. D. Harr. 1987. Comparative snow accumulation and melt during rainfall in forested and clear-cut plots in the western Cascades of Oregon. Water Resour. Res., 23 1), 135-142.

Brunengo, M.J. 1990. A method of modeling the frequency characteristics of daily snow amount, for stochastic simulation of rain-on-snowmelt events. Proc. West. Snow Conf., 58th Annual Meeting, 17-19 April 1990. Sacramento, California, 110-121.

Brunengo, M. J., S. D. Smith and S. C. Bernath. 1992. A GIS-based method of modeling water input from rain-on-snow storms, for management and regulation of clearcut forest harvest. Proc. West. Snow Conf., 60th Annual Meeting, 14-16 April 1992, Jackson Hole, Wyoming, 125 128.

Court, A. 1963. Snow cover relations in the Kings River basin, California. 7. Geophys. Res., 68 16), 4751-4761.

Gerdel, R.W. 1949. Evaluation of snow cover distribution from horizontal photographs. San Francisco, CA, U.S. Army Corps of Engineers. Cooperative Snow Investigations Progress Report, Misc. Rep 1.

Hall, R. L. and J. F. Hannaford. 1983. Analysis of three rain on snow floods in the Sierra Nevada, California. Proc. West. Snow Conf., 5lst Annual Meeting, 19-21 April 1983, Vancouver, Washington, 46-54.

Hannaford, J. F., R. L. Hall and A. J. Brown. 1979. Application of snowcovered area to runoff forecasting in the southern Sierra Nevada. Proc. West. Snow Conf.. 47th Annual Meeting, 18-20 April 1979, Sparks, Nevada, 5667.

Harr, R. D. 1981. Some characteristics and consequences of snowmelt during rainfall in western Oregon. 7. Hydrol., 53 (3-4), 277-304.

Hart, D. and F. Gehrke. 1990. Status of the California Cooperative Snow Survey program. Proc. West. Snow Conf., 58th Annual Meeting, 17-19 April 1990, Sacramento, California, 9-14.

Kattelmann. R. and B. McGurk. 1989. Water release for a low elevation snowpack in the Sierra Nevada. Proc. West. Snow Conf., 57th Annual Meeting, 18-20 April 1989, Fort Collins, Colorado, 141-144.

Kattelmann, R., N. Berg and B. McGurk. 1991. A history of rain-on-snow floods in the Sierra Nevada. Proc. West. Snow Conf., 59th Annual Meeting, 12-15 April 1991, Juneau, Alaska, 138 - 141.

Leavesley, G. H. and L. G. Stannard. 1990. Application of remotely sensed data in a distributed-parameter watershed model. In Kite, G.W. and A. Wankiewicz, eds. Proceedings of the Workshop on Applications of Remote Sensing in Hydrology, 13-14 February 1990, Saskatoon, Saskatchewan. Saskatoon, Sask., Environment Canada. National Hydrology Research Institute, 47-64. (NHRI Symposium 5.

McManamon, A., R. K. Hartman and R. Hills. 1995. Implementation of the Snow Estimation and Updating System (SEUS) in the Clearwater River basin, Idaho. Proc. West. Snow Conf., 63rd Annual Meeting, 1820 April 1995, Reno/Sparks, Nevada, 56 - 65.

McManamon, A., R. K. Hartman and R. Hills. 1995. Implementation of the Snow Estimation and Updating System (SEUS) in the Clearwater River basin, Idaho. Proc. West. Snow Conf., 63rd Annual Meeting, 1820 April 1995, Reno/Sparks, Nevada, 56 65.

Martinec, J. and A. Rango. 1987. Interpretation and utilization of areal snow-cover data from satellites. Ann. Glaciol., 9, 166-169.

Miller, D. H. 1962. Snow in the trees - where does it go? Proc. West. Snow Conf., 30th Annual Meeting, 16-18 April 1962, Cheyenne, Wyoming, $21-27$.

Parsons, W. J. and G. H. Castle. 1959. Aerial reconnaissance of mountain snow fields for maintaining up-to-date forecasts of snowmelt runoff during the melt period. Proc. West. Snow Conf., 27th Annual Meeting, 21-23 April 1959, Reno, Nevada, 49-56.

Pattee, S. and A. Kammereck. 1996. Early flood warning: forecasting in the Pacific Northwest. Proc. West. Snow Conf., 64th Annual Meeting, 16-18 April 1996, Bend, Oregon, 183-185.

Rango, A. 1993. Snow hydrology processes and remote sensing. Hydrol. Processes, 7 (2), 121-138.

Taylor, N. R. 1913. The rivers and floods of the Sacramento and San Joaquin watersheds. Washington, DC, U.S. Weather Bureau. (Bulletin 43.

U.S. Army Corps of Engineers, 1956. Snow hydrology: summary report of the snow investigations. Portland, OR, U.S. Army Corps of Engineers. North Pacific Division.

U.S. Army Corps of Engineers. 1991. American River watershed investigation, California: feasibility report. Sacramento, CA, U.S. Army Corps of Engineers. Sacramento District. 